\title{
Entrepreneurial and Functional Building Technology Education as a Means of Achieving Vision 2020 in Nigeria
}

\author{
*Igwe, C.O ${ }^{1}$, Puyate, S.T2 ${ }^{2}$ Onoh, C.E.C ${ }^{3}$, Eze, C.J ${ }^{1}$ \\ ${ }^{1}$ Federal University of Technology, Minna \\ ${ }^{2}$ Rivers State University of Science and Technology, Port Harcourt \\ ${ }^{3}$ Enugu State University of Technology, Enugua \\ *christoigwe@yahoo.com
}

\begin{abstract}
Entrepreneurial and functional building technology education, if well positioned has the potentials of launching Nigeria into the first 20 world economies by the year 2020. This paper integrates the industrial, educational and entrepreneurial activities that results in increased productivity. Functional building technology career broadly categorised into professional and non-professional. The paper reviewed the entrepreneurial prospects open to the non-professional builders trained in the technical institutions equipped with the knowledge and skills to competently perform in the building construction sites as craftsmen, technicians and technologist. Also, other entrepreneurial activities in the public and private sectors at both small and medium scale capacity. The review presented inadequate budgetary allocation to the education sector, dearth of infrastructural facilities, also, the gap existing between the construction industry and the technical institutions. It recommended, increased funding and acquisition of modern equipment/machine and adequate infrastructural facilities. Also, establish a sustainable linkage between the construction industry and technical institutions. Implementation of these will result in increased productivity, robust economy and actualization of the nation's vision 2020 .
\end{abstract}

Keywords: Entrepreneurial, Functional Building Technology Education, Vision 2020 and Nigeria

\section{Introduction}

Nigeria's Vision 2020 is a mental picture of the future of the nation representing improvements on the status quo such that by 2020 , Nigeria will be one of the 20 largest economies in the world able to consolidate its leadership role in Africa and establish itself as a significant player in the global economy and political arena (FGN, 2008). According to Haan (2006) entrepreneurship education programmes help develop attitudes favourable to starting one's own business and provide knowledge and skills for running a business. Skill development encompasses a broad range of core skills so that individuals are equipped for productive activities and employment opportunities. Igwe (2008) further emphasised that entrepreneurship education is the type of education that equips the citizen with the right training and motivation they need to be self-reliant and job creators thereby reducing unemployment to the beeriest minimum. A nation that her citizens are gainfully employed cannot suffer poverty and hunger. Functional building technology and entrepreneurship education will prepare the individual for a work life, increased productivity and ability to market his product profitably. Entrepreneurship skills and functional trade is a key component of secondary education curriculum as presented by Orji (2011) who noted that the new secondary school education curriculum builds on gains of the Basic Education Curriculum and targets allround development of every individual student. That is, it involves preparation for higher education; functional trade and entrepreneurship skills; and strengthening of ethical, moral and civic values. According to him, trade and entrepreneurship is a major component of the new senior secondary education curriculum and is designed to address the dearth of technical skills amongst growing demand for the services of the skills in Nigeria. Career in Building technology can be categorised into the professionals and non-professionals. The professionals refers to registered builders with the council of Registered Builders of Nigeria (CORBON, 2010) While the non-professionals are technicians and craftsmen who are skilful in building constructions practices but not registered with CORBON. The Nigerian Institute of Building (NIOB) brought these technicians, artisans and craftsmen together for periodic training to enhance their performance. This paper considers the non-professional builders' opportunities and prospects open to them in combining their entrepreneurial and technical skills towards contributing to the built environment and national productivity.

Technology education is a time-honoured process, which deals with acquisition of skill and knowledge in chosen occupation to enable an individual to earn a living. This type of education helps to identify 
potential in individuals, develop it to the degree at which the individual skills, knowledge and attitude required for employment in a particular occupation, group of related occupations or to function in any economic activity including agriculture, commerce, public and private service (Igwe, 2008). At different educational levels, technology education aims at the production of low to high-level manpower but the degree of the scientific knowledge and the skill acquired has been an indication of the effectiveness of the content, organisation and the teaching method employed. Programmes in technology education are organized and designed to equip one with work and life skill, which include divisions such as trade, industrial education, agricultural education, occupational or vocational business education, fine and applied arts, distributive education, home economic and technical education (Adebayo, 2005). According to Imoko (2002), developing countries need to improve productivity throughout the economy if they are to compete successfully in this era of rapid economic and technological change. To achieve Vision 2020 will not require only capital investment, but also a workforce that has the flexibility to acquire skills for better operations. In advanced countries of the world, in spite of their high level of economic and industrial development, still accord priority to technology education and entrepreneurship as the basis of economic sustainability. The citizens are responsible, creative and innovative enough to identify, establish and run their own ventures despite the constraints. These attitudes help them to develop themselves, communities, create jobs for others, supplement social infrastructural amenities and develop the nation. These attitudes are seriously lacking in developing countries, which has worsened the state of their economies. It is against this backdrop that this paper explores entrepreneurial and functional building technology education as a means of achieving Nigeria's Vision 2020.

\section{Entrepreneurship Development in Nigeria}

Nigeria in the olden days was engaged in entrepreneurship. Early entrepreneurship is characterized with production or manufacturing in which case the producer most often started with a small capital, most of it from his own savings. Early entrepreneurship started with trade by barter even before the advent of any form of money. The coming of the colonial masters marked the beginning of the modern entrepreneurship development. They brought in their wears and made Nigerians their middlemen. Most modern entrepreneurs were engaged in retail trade or sole proprietorship. With the introduction of formal education, people had the opportunity of being employed in the civil service, because those days the prestigious occupation can take most Nigerians and their goods. As such, the system made Nigerians to be dependent on the colonial masters. Again, the contrast between Nigerian and foreign entrepreneurs during the colonial era was very detrimental and the competitive business strategy of the foreign entrepreneurs was ruinous and against moral standards established by society. They did not adhere to the theory of "live and 'lets' live". For instance, the United African Company (UAC) that was responsible for a substantial percentage of the import and export trade of Nigeria, had the policy of dealing directly with producers and refused to make use of the services of Nigerian entrepreneurs. The refusal of the expatriates to utilize the services of local businessmen inhibited their expansion and acquisition of necessary skills and attitude. Because of this, many eventually folded up. As a result, the flow of entrepreneurship in the country was slowed down. But with more people being educated and the fact that government could no longer employ most school leavers, economic programmes to encourage individuals to go into private business and be self reliant were initiated (Nicks, 2008). Nigeria has adopted several entrepreneurship development programmes as its strategy for combating her economic crises and emerge the $20^{\text {th }}$ largest economies in the world by the year 2020. The oil boom of the 1970 s led to expansion of educational programmes but without corresponding increase in job opportunities. Consequently, there was an explosion of unemployment, worsened by the mass retrenchment of workers brought about by the contraction of the civil service necessitated by the recession in the oil market and global economic crisis.

The federal government as well as several state governments launched entrepreneurship development programmes some of which includes: National Directorate of Employment (NDE), National Poverty Eradication Programme (NAPEP), National Economic and Empowerment Development Scheme (NEEDS), National Centre for Technology Management (NACETEM), SMEDAN, Small and Medium Enterprise (SME) and others. Entrepreneurship is a prime mover of change that plays a strategic role in the development of SME, which forms the bedrock of any nation's industrial and economic take off especially in a typical developing country like Nigeria. The advantages of SMEs' against large multi-national companies in developing countries are enormous. Ekong (2008) believes that Nigeria's national development hinges, in part, on the issue of enterprise culture based on an economic policy that places emphasis on commercial involvement and development of imaginative blue prints. Large-scale enterprises are more susceptible to 
economic recessions than SMEs'. This is because the financial base of the multi-nationals is in the international financial institutions; therefore, any stress in the international financial institution will affect the multi-national companies. SMEs' are mostly financed locally and their raw materials are sourced locally. Problem related to importation of sophisticated technology, highly skilled personnel and foreign exchange transactions that may make businesses to be tied to international transactions and the associated risks do not affect SMEs'.

Nigerian's Vision 2020 and Entrepreneurship: No economic venture survives without the initiative, resourcefulness, drive, hard work, innovation and optimism of the entrepreneur. Onanaye and Ebenezer (2008) believe that there is a connection between the level of development of a nation and level of human capability in creativity and innovation. They asserted that the reference to developed, as against the developing nations, is due, mainly to the stage of economic development of a country. Entrepreneurship is an indispensable factor in economic development. Whether an enterprise employs five, five hundred or five hundred thousand staff, they all contribute to economic development of a nation. Hisrich, Peters and Shepherd (2008) defined entrepreneurship as the process of creating something new with value by devoting the necessary time and effort assuming the accompanied financial and social risks and receiving the resulting rewards of monetary and personal satisfaction and independence. Entrepreneurship is the willingness and ability of an individual to seek out investment opportunities in an environment, and be able to set up an enterprise and run it successfully based on the identified opportunities. It is also the process of creating something new with value by devoting the necessary time and effort needed, as well as assuming the accompanying risk and the reward that follow. The entrepreneur is not just involved with the establishment of a business enterprise, but he is also an originator of profitable business ideaconcepts synonymous with skilled work. He is an inventor who has ideas of new technological processes and products expected to bring about discrete dynamic change in technological development in a given society. Facts are clear as daylight that China is going to attain an unprecedented position as a super global economic power. Michael (2005) put up a pragmatic analysis of the real situation and trend arriving at three fundamental conclusions that enabled China to steadily accelerate its pace of economic development - the fast expanding entrepreneurship, a high level of technical education and the formation of its own silicon valley. Another distinctive advantage of China is that most of the native born Chinese who receive education in the USA would return to start companies in China. Chinese expenditure on research and development tripled and continues to climb. In addition to building new public institutions and expanding capacity at existing institutions, much of the enrolment growth over the last decade resulted from the relaxation of the laws governing private education. Today, there are more than 1,300 private tertiary institutions operating in China, of which more than 300 are affiliated with public universities.

According to Encyclopaedia Britannica (1973), a vision is the power of seeing or imaging, looking ahead, grasping the truth that underlies facts, this means the power to use one's mind eyes to design a picture of the future. It is a clear mental picture of the future, which must represent a significant improvement on the current state. The vision statement - By 2020 Nigeria will be one of the largest economies in the world able to consolidate its leadership role in Africa and establish itself as a significant player in the global economic and political arena. To achieve the above Vision 2020, President Musa Yar'Adua (late) on $21^{\text {st }}$ April 2008 inaugurated the institutional framework of Vision 2020 for the development and implementation of the vision, which include:

- The National Council on Vision 2020 (NCV 2020)

- $\quad$ The National Steering Committee (NSC)

- The National Technical Working Groups (NTWGs)

- $\quad$ Stakeholders Vision 2020 Development Committee

- $\quad$ Economic Management Team (Official Website 1.0.0 Nigeria Vision 2020).

\section{Non - Professional Builders and Entrepreneurial prospects}

Knowledge and skill acquisition are the keys for unlocking the treasures in both human and natural resources. More so, the most important factor of all economic development comes out of the mind of man. Human resources development therefore, has a multiplier effect on effective utilization of all other resource. Anderson (2002) noted that technical and vocational education has fuelled the engine of economic growth and productivity in western industrialized nations. Technology education plays an important role in developing the human resources required for teaching as well as for industrial, commercial and business (Entrepreneurship) sectors for sustainable growth and national development. 
The fundamental challenge of the under developed countries is not the lack of natural resources but under development of her human resources in the area of skill acquisition. In today's technological world, a broad based system for education and training is more essential than even national resources. Training according to Nwadiani (2011) is a process of learning geared towards the acquisition of a skill or skills by the trainee from the trainer. This process of skill learning could be formal, informal and non-formal settings. Therefore, these tripartite terms are geared towards one purpose and that is to prepare worker on the job. The economic and technological growth of any nation depends on its functional technology education system. The importance of functional building technology education in entrepreneurship in the realization of Nigeria's Vision 2020 is of no small measure as this programme trains and prepare individuals in many areas of skills such as masonry, brick/block laying, plumbing, iron bending, carpentry, electricians, tillers and painters. Other aspects of building technology education with entrepreneurial prospects include brick/block moulding, concrete rings and culverts, POP moulding, casting of concrete for different purposes, casting and moulding of balustrades, column covers and casting and moulding of interlocks all of which are of great importance in adding structural and aesthetic values to buildings and with high market values in the competitive race among individuals for building the most magnificent mansion in the society.

Proper integration of building technology education graduates into entrepreneurial activities will promote and improve the economy in realizing the nation's Vision 2020. It is one thing to acquire skills and a more herculean task to market the acquired skilled thereby profiting the individual and society. That is the meeting point of building technology and entrepreneurship. Technology education provides the manipulative technical skills while entrepreneurship transforms it to saleable services to humanity through industrial and educational sectors thereby yielding profit to the entrepreneur and increased productivity and economic growth to the nation. Building technology education trains potential entrepreneurs in the various building technology skills to be able to establish and operate small-scale companies like those that block industry, production of pre-cast concrete elastic poles, concrete rings, culvert, flowerpots, interlocking tiles, fancy blocks, bricks etc. These building materials will be of high quality and quantity as may be needed by the construction sites and industries. Building technology graduates also have the option of being a foreman, craftsmen, and technicians in building construction sites. With the presence of other building parties, the problem of buildings failure will be checked. Atsumbe (2002) affirmed that the survival of any industry is largely dependent on the calibre of its technicians and craftsmen. Building technology education creates opportunities at the construction site, marketing of building materials, vocational \& technical education institutions to mention but a few. Whatever choice immures the entrepreneur from unemployment makes him self-reliant and contributes to sustainable national development and the achievement of Vision 2020.

\section{Challenges in Nigerian Entrepreneurial and Functional Technology Education}

Inadequate Budgetary Allocation: United Nations Development Programme (2010) Report, as cited in Wapmuk (2011) also indicates that Nigeria's Human Development Index (HDI) is 0.423, thus, ranking Nigeria 142 out of 169 countries surveyed. About education, which is the basis for self- reliance, budgetary allocation to education in Nigeria has not met the UNESCO standard of $26 \%$ of nation's annual budget (Wapmuk, 2011). No wonder Yahaya (2011) observed that even though Nigeria is richly endowed with natural resources, she remains poor and so we are classified as a low-income country. Wapmuk,

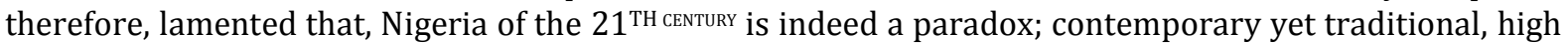
on resource potential, but low realisation of potentials while there is over reliance on government, government cannot however, meet the numerous contending demands.

Dearth of Infrastructural Facilities in Technology Institutions: Training in the functional technology and entrepreneurship education demand huge and enormous resources, materials and facilities. The National policy on education (2004), affirms that the principle behind technology education and nurturance of trainers to be experimental, exploratory and challenging to the utmost is strongly tied to the availability and quality of infrastructural facilities in the institutions. Evans (2000) in a review of resource allocations in Chinese education, noted that, although, there as scarcity of senior scientists in research institutes yet the young scientist's recorded excellent scientific and technological performances having been trained with the best pieces of equipment available in the world. In Nigeria, the challenges ranges from harsh conditions and environment, lack of basic infrastructures, use of obsolete machines and equipment. All these adversely affect the quality of graduates from these institutions as they hardly could meet the labour market requirements and standards, locally and globally. According to the 2003 
reports of the American Business Higher Education Forum, even if employees are equipped for today's job, they need to be ready to learn, re-learn, and in some cases unlearn to respond to corporate downsizing, workplace modifications and other realities. Indeed, today's employees also need a higher level of technical and entrepreneurial skills than their counterparts do in decades past.

Inadequate Linkage between the Construction Industry and Technical Institutions: United Nation Educational, Scientific and Cultural Organisation (UNESCO, 1999) observed that the mismatch of curriculum in technical education with the needs of the industry is a key issue in co-operation between school and industry, not only in African countries but also worldwide. Hence, UNESCO suggested the setting up of mixed curricular review in technical education. The objective of entrepreneurial and technology education programme is to provide business and industry with a pool of adequate and well trained technical manpower, the co-operation of industry is therefore essential for the attainment of programme objective. The school industrial linkage through training programme emerged in the school curriculum as an instructional strategy for solving the problems of inadequate facilities, personnel, infrastructure and other constraints, which impose severe limitations on the capacity of schools to achieve their mandate. According to industrial training fund (2000), the scheme was designed to provide on the job practical experience for the students undergoing all courses that demand exposure in industrial activities during their college programme. One of the major problems associated with school industry relationship is lack of commitment on the part of the industry. Ogalanya (2000) noted that although the bulk of the trained employees of the industry were products of technical institutions, most employees were yet to show greater commitment and involvement.

\section{Conclusion and Recommendations}

Nigeria's Vision 2020 would be achieved if building technology education, which blends the industrial, educational and entrepreneurial activities in the country, is given the needed financial and technical support. The non-professional builders operating in the construction industry can make huge contributions in both the public and private sector of the economy. Encouraging SMEs' programmes and creating an enabling environment for potential building entrepreneurs will accelerate the nations' productivity, get rid of unemployment and other social vices in the society and place the nation on the path to achieving her laudable Vision. Technical education institutions that trains the technicians, craftsmen and technologists having a curriculum as contained in the National Policy on Education (2008) is saddled with challenges ranging from inadequate funding, lack of infrastructural facility, obsolete machines and equipment, ineffective linkages between technical institutions and construction industry among others. The following recommendations should be implemented to actualize vision 2020 in Nigeria through entrepreneurial and functional building technology as a means of achieving vision 2020 in Nigeria.

- Increased budgetary allocation to meet the UNESCO standard of $26 \%$ of nation's total annual budget to education.

- Acquisition of modern machines, equipment and infrastructural facilities in the technical institutions.

- Bank of industry and non-governmental organisation should provide adequate financial support through soft loans to small/medium entrepreneurs to be self-reliant.

- The industrial sector should engage the services of building graduates from the technology institutions in construction sites and closely supervised by professional builders.

- The products of non-professional building entrepreneurs should be patronised by Nigerians and others instead of imported building materials and products.

- Technology institutions should organise workshop in partnership with the industrial sector and professional bodies (NIOB, CORBON, and NATT) to upgrade them on the latest global practice.

- Construction industries to do a joint periodic review and updating of curriculum content and programmes. 


\section{References}

Adebayo, S. A. (2005). Technology education as a vehicle for Nigeria industrial transformation and youth development. A paper presented at the $18^{\text {th }}$ Annual National Conference of Nigerian Association of Teachers of Technology (NATT), Rivers State.

Anderson, D. (2002). Productivism, Sustainable Development and Vocational Education and training. International conference on post-compulsory education and training. $10^{\text {th }}$ Australia, 2002 Brisbane Australian Academic Press. Retrieved on 15/7/2008 from http://www.avetra.org.au/conference Archives/2003/documents/PA 066 Anderson.pdf.

Atsumbe, B. N. (2002). Needed improvement in the curriculum of technical college mechanical engineering curriculum. Unpublished PhD Thesis. Department of vocational teacher education, University of Nigeria, Nsukka.

CORBON. (2010) List of Registered Builders Entitled to practice in the Federal Republic of Nigeria. CORBON Publication, Abuja, Nigeria.

Ekong, A. O. (2008). Entrepreneurship Education; a positive redirection for Nigeria's national development. Journal of Educational Innovators, 1(1), 1-16.

Evans, M. O. (2000). Trend and uses it in gifted education programme New York. Me Graw Hill.

Federal Republic of Nigeria (FGN). (2004). National Policy on Educations, Lagos Nigeria: Federal Government Press.

Haan, C. (2006). Training for work in the informal micro-enterprise sector: fresh evidence from subSahara Africa. Dordrecht, Netherland: Springer.

Hisrich, P. \& Shepherd, D. (2008). Entrepreneurship. McGraw-Hill/Irwin. New York.

Igwe, C. O. (2008). Entrepreneurship Education: Nigeria imperative for achieving millennium development goals. Journal of Vocation Technical and Business Education, 3(1), 271-276.

Igwe, C. 0. (2008). Technology Education: A vehicle for sustainable youth empowerment in Nigeria. Applied Psychology Selected Reading, 5(1), 88 - 94.

Imoko, I. O. (2002). Improving on practical skill content of senior secondary school metalwork curriculum. Unpublished B.Tech Thesis. Federal University of Technology, Minna.

Industrial Training Fund (ITF). (2000). Students Industrial Work Experience Scheme (SIWES) in human development in Nigeria. Jos. ITF Publication.

Michael, R. (2005). China's technological and entrepreneurial advancement. MSNBC.

Nicks, L. (2008). The history of entrepreneurship in Nigeria. May, $24^{\text {th }}$.

Ogalanya, G. A. O. (2000). Strategies for extending school industry relationship to technical college programmes. Unpublished PhD thesis, University of Nigeria, Nsukka.

Onanaye, A. S. \& Ebenezer, O. S. (2008). Information and Communication Technology (ICT) in Education: Implications for entrepreneurship education for national development. Journal of Education Innovations, 1, 81-105.

Orji, N. S. (2011). The new senior secondary curriculum: Trade/Entrepreneurship. A paper presented at a 2-day sensitization and advocacy workshop for teachers in Adamawa State held in Yola 21-22 September.

Wapmuk, L. S. (2011) Education and self-reliance in 21 $1^{\text {st }}$ century Nigeria. A Keynote address presented at the conference organised by academic fund of the Federal College of Education, Pankshin, on $8^{\text {th }}$ June.

Yahaya, H. (2011). Education reforms in Nigeria: past, present and future. Reform in Nigeria. 22-29. Lagos: Stirling-Horden Publisher Ltd.

Yar'Adua U. M. (2008). President's address at the inauguration. Official website 1.0.0 Nigeria vision 2020 Downloaded on 15/07 